\title{
$\mathrm{JAK} 2$ 돌연변이를 동반한 폐색전증 1 예
}

가톨릭대학교 의과대학 ${ }^{1}$ 내과학교실, ${ }^{2}$ 진단방사선학교실

김진진 ${ }^{1}$, 권순석 ${ }^{1}$, 이현정 ${ }^{1}$, 이혜연 ${ }^{1}$, 정명희 ${ }^{2}$, 김용현 ${ }^{1}$

\section{A Case of Pulmonary Thromboembolism with JAK2 Mutation}

\author{
Jin-Jin Kim, M.D. ${ }^{1}$, Soon-Seog Kwon, M.D. ${ }^{1}$, Hyun-Jeong Lee, M.D. , Hea-Yon Lee, M.D. ${ }^{1}$, Myung-Hee Jeong, \\ M.D. ${ }^{2}$, Yong-Hyun Kim, M.D. ${ }^{1}$ \\ Departments of ${ }^{1}$ Internal Medicine, ${ }^{2}$ Diagnostic Radiology, The Catholic University of Korea College of Medicine, Seoul, Korea
}

The incidence of pulmonary thromboembolism increases with age. The risk factors of pulmonary thromboembolism include surgery, malignancy, obesity, lupus anticoagulants, and vascular conditions such as deep vein thrombosis. Thromboembolism in younger patients or in unusual locations, the possibility of primary thrombophilic conditions should be considered. Primary thrombophilic states include myeloproliferative disorders (MPD). JAK2 V617F mutation is found commonly in patients diagnosed with MPD, in 90 95\% of polycythemia vera (PV) and in 50 $60 \%$ of essential thrombocytosis (ET) patients. Sometimes the JAK2 V617F mutation is found in cases without MPD. The relationship between JAK2 V617F mutation and thrombosis has not been defined. Recently, clinical evidence suggests that this mutation may be variably associated with thrombosis. We present one case of pulmonary thromboembolism in a young patient, who was positive for the JAK2 V617F mutation and did not have MPD.

Key Words: Pulmonary thromboembolism, JAK2 V617F mutation, Young age, Myeloproliferative disorder

\section{서 론}

폐색전증의 발생률은 연령이 증가함에 따라 급격히 증 가하며 45세 이하에서는 남자에서, 60 세 이상에서는 여자 에서 발생률이 높다. ${ }^{1}$. 폐색전증의 위험 인자는 수술, 악성 종양, 비만, 임신이나 경구 피임제 복용, 혈관 내 장치 삽 입 등이다. 폐색전증이 젊은 나이에 발생하거나 반복적으 로 또는 흔하지 않은 위치에 발생하는 경우 원발성 응고 장애 여부를 확인해야 하며 이에는 C 단백질, S 단백질 또는 안티트롬빈 결핍이나 과호모시스테인혈증, $\mathrm{V}$ 응고인 자 레이덴 돌연변이 등이 있다 ${ }^{2}$ JAK2 유전자의 617번째 염기서열의 단일 점돌연변이(이하 JAK2 V617F 돌연변이)

Address for correspondence: Yong-Hyun Kim, M.D. Department of Internal Medicine, Holy Family Hospital, The Catholic University of Korea College of Medicine, 2, Sosadong, Wonmi-gu, Bucheon 420-717, Korea

Phone: 82-32-340-2114, Fax: 82-32-340-2255

E-mail: kyh30med@catholic.ac.kr

Received: Jul. 29, 2009

Accepted: Aug. 31, 2009
는 필라델피아 염색체 음성인 골수증식성 질환인 진성적 혈구 증가증, 원발성 혈소판 증가증, 골수섬유화증에서 볼 수 있으며 골수증식성 질환이 있는 환자는 그렇지 않은 경우에 비해 혈전증이 발생할 위험이 더 높다. 그러나 JAK2 V617F 돌연변이와 혈전증 발생률과의 연관성은 아 직 정립된 바가 없어 논쟁의 여지가 있다. 하지만 홍콩의 대학 병원에서 원발성 혈소판 증가증 환자를 대상으로 시 행한 연구에서 혈전증이 발생한 환자의 $32 \%$ 에서 JAK2 $617 \mathrm{~F}$ 돌연변이가 양성이었으며 JAK2 617F 돌연변이 음성 환자에서는 9\%만이 혈전증이 발생하여 JAK2 617F 돌연 변이가 혈전증과 관련이 있다는 것을 시사하고 있다. ${ }^{3}$. 따 라서 다른 위험 인자 없이 45세 이하에서 발생한 폐색전 증에서 원인을 찾기 위한 검사를 시행할 때 JAK2 617F 돌연변이를 고려해 보아야 하겠다.

저자들은 45 세 남자에서 말초 혈액 검사상 이상이 없어 골수 증식성 질환을 의심할 수 없는 상황에서 JAK2 617F 돌연변이가 동반되고 다른 폐색전증의 위험 인자를 찾을 수 없는 폐색전증 1 예를 경험하였기에 이를 문헌고찰과 함께 보고하는 바이다. 
JJ Kim et al: Pulmonary thromboembolism related to JAK2 mutation

\section{증 례}

\section{환 자: 45세, 남자 \\ 주 소: 호흡곤란}

현병력: 내원 하루 전 우측 다리의 통증이 생겼고 내원 직전 호흡곤란이 발생하여 내원하였다. 기침, 가래, 객혈 등은 호소하지 않았다.

과거력: 2년 전 당뇨 진단 받았으나 투약력은 없었다.

가족력: 특이 소견 없었다.

흡연력: 60 갑년

직업력: 자영업

여행력: 특이 소견 없었으며 최근 활동량에도 변화 없 었다.

이학적 소견: 내원 당시 혈압은 $100 / 70 \mathrm{mmHg}$, 맥박수 분당 90 회, 호흡수 분당 20 회, 체온 $36.0^{\circ} \mathrm{C}$ 로 정상 소견 보였다. 의식은 명료하였고, 흥부 청진소견에서 양측 폐 야의 호흡음은 정상이었으며 심음은 규칙적이고 잡음은 없었다. 복부진찰에서 특이소견은 없었으며, 오른쪽 하지 에 부종이 관찰되었다.

검사실 소견: 내원 시 시행한 동맥혈 가스 검사 소견은 $\mathrm{pH} 7.405, \mathrm{PaCO}_{2} 24.7 \mathrm{mmHg}, \mathrm{PO}_{2} 48.7 \mathrm{mmHg}, \mathrm{HCO}_{3}{ }^{-}$ $15.3 \mathrm{mmHg}$ 로 저산소증 소견 보였으며 호흡성 염기증과 대사성 산증이 동반된 혼합형 산염기장애로 생각되었다. 호흡성 염기증의 원인은 폐색전증, 대사성 산증의 원인은 혈장 음이온차가 $17.7 \mathrm{mEq} / \mathrm{L}$ 로 증가되어 있어 금식으로 인한 케토산증으로 생각되었다. 말초 혈액 검사에서 혈색 소 $16.8 \mathrm{~g} / \mathrm{dL}$, 헤마토크리트 $49.3 \%$, 백혈구 $12,400 / \mathrm{mm}^{3}$,
혈소판 $150,000 / \mathrm{mm}^{3}$, 일반 혈액 화학 검사에서 공복혈당 $116 \mathrm{mg} / \mathrm{dL}$, 혈중요소질소 $16.6 \mathrm{mg} / \mathrm{dL}$, 크레아틴 $0.9 \mathrm{mg} /$ $\mathrm{dL}$, 총 단백 $7.1 \mathrm{~g} / \mathrm{dL}$, 알부민 $4.2 \mathrm{~g} / \mathrm{dL}$, 아스파라진산아미 노전이효소(AST) $30 \mathrm{IU} / \mathrm{L}$, 알라닌아미노전이효소(ALT) $27 \mathrm{IU} / \mathrm{L}$, 총 빌리루빈 $1.1 \mathrm{mg} / \mathrm{dL}$, 직접 빌리루빈 0.4 $\mathrm{mg} / \mathrm{dL}$, 혈청 나트륨 $138 \mathrm{mEq} / \mathrm{L}$, 칼륨 $4.0 \mathrm{mEq} / \mathrm{L}$ 이었다. D-이합체(D-dimer)는 $472 \mathrm{ng} / \mathrm{mL}$ (rapid immunoassay, 참고치 0 $322 \mathrm{ng} / \mathrm{mL}$ )이었다. 공복시 호모시스테인 농도 는 $10.66 \mu \mathrm{mol} / \mathrm{L}$ (참고치 $3.7 \sim 13.9 \mu \mathrm{mol} / \mathrm{L}$ )이었고 항 핵항체검사(ANA)는 $1: 100$, 항카디오리핀항체, 항중성 구세포질항체(ANCA) 및 항이중가닥디엔에이항체(Anti$\mathrm{dsDNA}$ antibody)는 음성이었다. C 단백질 활성도는 $49 \%$ (참고치 70 130\%)로 약간 감소되어 있었고 그 외 S 단백 질 활성도는 118\% (참고치 77 143\%), V 응고인자 레이 덴 돌연변이는 음성이었고 프로트롬빈 유전자 돌연변이 검사는 시행하지 않았다.

심전도 및 방사선학적 소견: 흥부 X-선 검사에서 특이 소견은 보이지 않았다. 환자의 심전도는 심박수 분당 88 회, 정상 동조율을 보이고 특이소견은 없었다.

흥부 컴퓨터 단층 촬영에서 양측 폐동맥, 폐엽사이동맥 (interlobar arteries), 폐하엽동맥, 폐중엽동맥, 혀부분폐동 맥(lingular segmental arteries)에서 다수의 색전을 보이 고 있었으며, 이 색전들은 우상엽의 후부분분지, 우하엽의 앞안쪽분지 및 좌하엽의 뒤바깥쪽 바닥 구역동맥(posterolateral basal segmental arteries)에서도 관찰되었다 (Figure 1).

또 하지 도플러 검사에서 우측 넙다리 정맥(right femo-
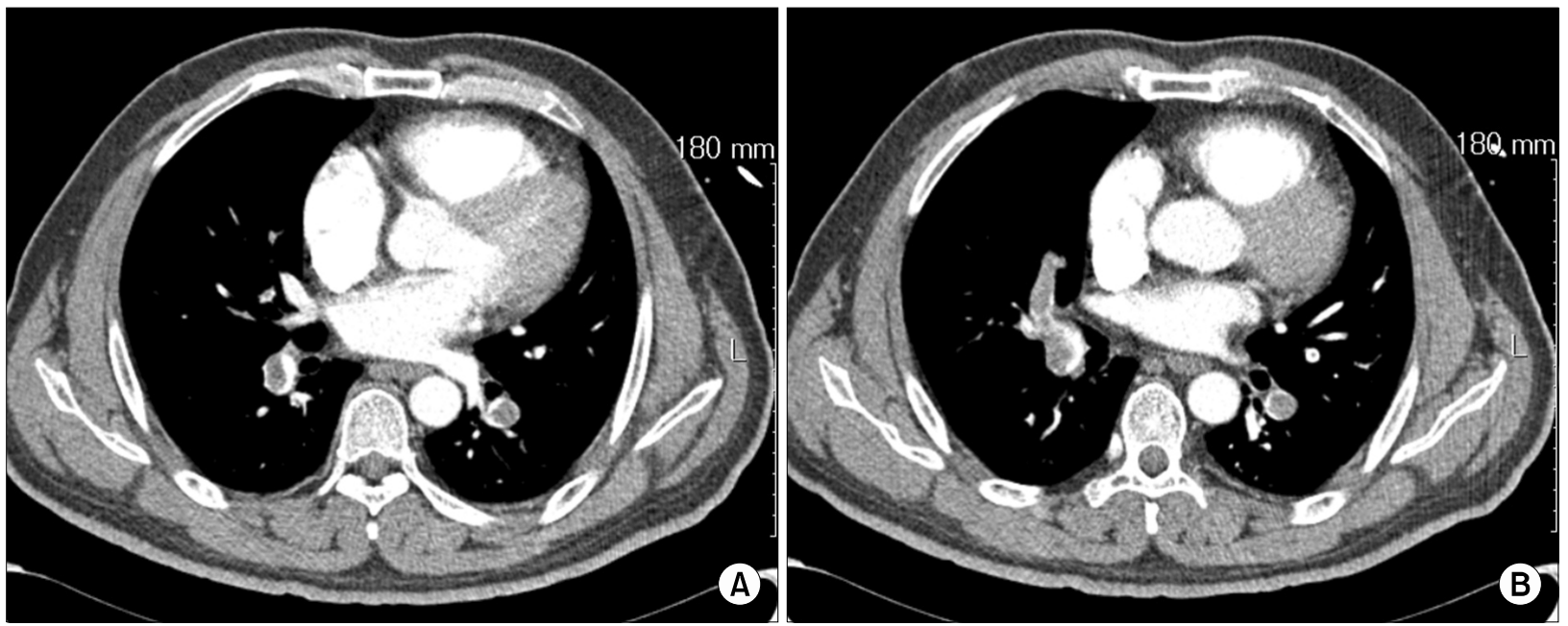

Figure 1. Chest CT scan shows multiple low densities in both pulmonary arteries (A), and in lobar arteries (B). 

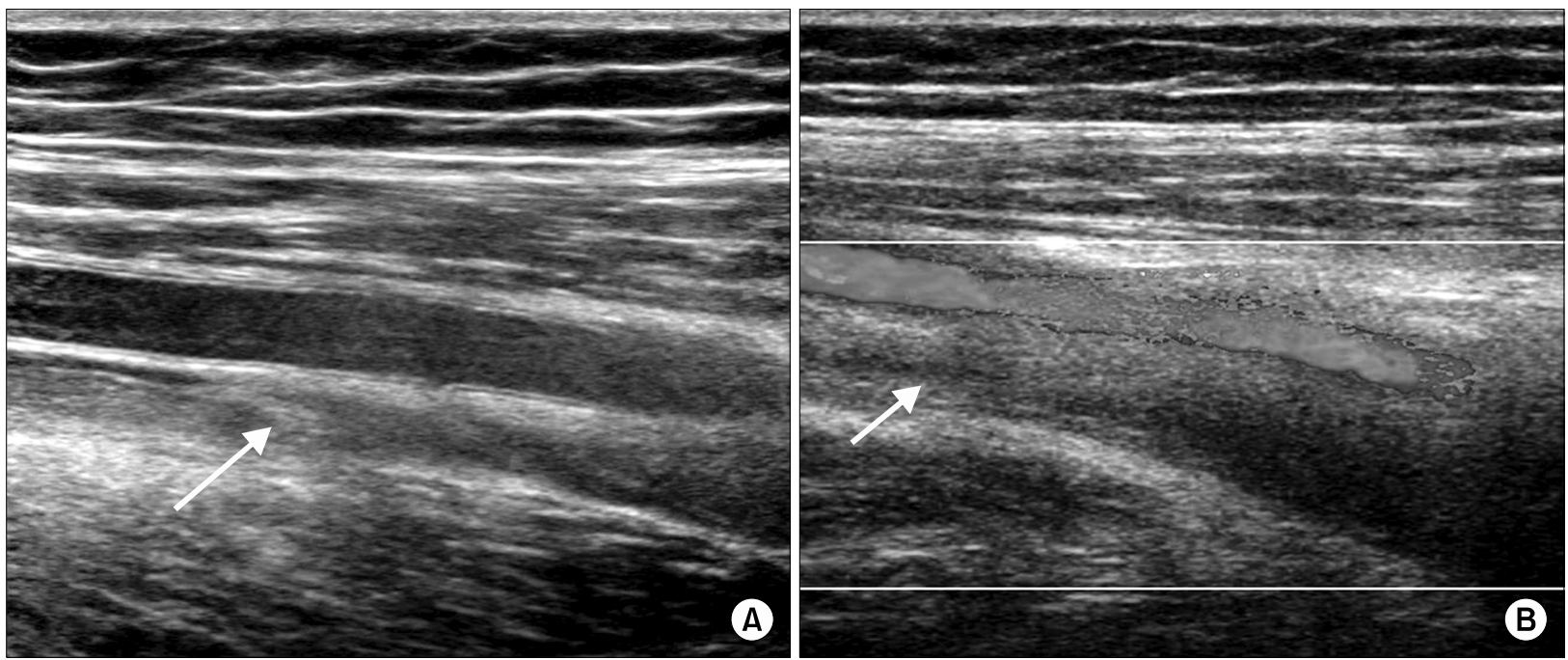

Figure 2. Doppler ultrasonogram shows echogenic lesion (arrow) in Rt. femoral vein (A) and no blood flow in same lesion (B).

ral vein) 내에 에코발생병소가 보이고 도플러로 확인한 결과 혈류가 감소되어 있어, 심부혈전을 진단할 수 있었다 (Figure 2).

임상경과 및 치료: 입원 당일부터 헤파린(enoxaparin) $60 \mathrm{mg}$ 을 12시간마다 피하 주사하였고, 와파린(warfarin) $5 \mathrm{mg}$ 을 경구 투여하였다. 내원 3일 후부터 호흡곤란 및 우측 다리 통증이 호전되었다.

중합효소연쇄반응 전기연동으로 직접 염기 서열을 분 석하여 검사한 JAK2 유전자 검사에서 $\mathrm{V} 617 \mathrm{~F}$ 점돌연변이 가 확인되었고 그 외의 유전자 돌연변이에 대해서는 확인 된 바가 없었다.

환자는 12 병일째 퇴원 후 와파린을 복용하면서 외래에 서 경과 관찰하였다. 10 개월 동안 와파린을 복용하면서 D이합체 및 흥부 컴퓨터 단층 촬영을 시행하였고 폐색전증 이나 심부혈전정맥증의 재발은 보이지 않아 와파린 복용을 중지한 상태로 외래에서 18 개월째 추적 관찰 중이다.

\section{고 찰}

원발성 응고장애의 원인에 대한 조사가 필요한 경우는 45세 이전에 발생한 정맥 혈전색전증, 혈전색전증이 반복 적인 경우, 혈전증이 장간막정맥이나 대뇌정맥과 같은 흔 하지 않은 부위에 발생했을 때, 정맥 혈전증의 가족력이 있는 경우, 반복적인 유산의 기왕력이 있는 경우이다. ${ }^{4}$. 폐 색전증을 일으킬 수 있는 원발성 응고 장애로는 안티트롬
빈 III 결핍, C 단백질 결핍, $\mathrm{S}$ 단백질 결핍, $\mathrm{V}$ 응고인자 레이덴 돌연변이, 프로트롬빈 유전자 돌연변이, 플라즈미 노겐 결핍 등이 있으며 이외에 지단백 a 상승, 과호모시스 테인혈증도 연관성이 있다.

본 증례 환자의 경우 환자의 연령은 45 세로 비교적 젊은 나이이며 문진에서 폐색전증의 위험요인은 발견되지 않았 다. 검사실 검사에서 과호모시스테인혈증은 보이지 않았 고 안티트롬빈 또는 $S$ 단백질 결핍도 관찰되지 않았다.

C 단백질 활성도가 감소되어 있었으나 혈전증이 발생 한 직후에 검사하는 경우 C 단백질의 활성도가 감소할 수 있으며 이와 같은 후천성 C 단백질 결핍의 원인으로는 간 질환, 비타민 $\mathrm{K}$ 결핍, 패혈증, 와파린 치료를 한 경우 등이 있다. 또한 혈전증의 과거력, 가족력이 없는 사람들도 200 명에서 500 명 중의 한 명은 C 단백질 활성도의 감소를 보일 수 있고, C 단백질 결핍 환자에서 C 단백질 활성도는 혈전증의 비교위험도를 잘 나타내지 못하기 때문에, C 단 백질 활성도만 저하된 소견으로는 본 증례 환자의 혈전증 을 설명하기는 어려울 것으로 생각되었다. 또한 외래 추 적관찰 도중 시행한 C 단백질 활성도가 정상 범위에 있어 $\mathrm{C}$ 단백질 결핍으로 인한 혈전증의 가능성은 낮은 것으로 판단하였다.

프로트롬빈 유전자 돌연변이 검사는 시행하지 않았으 나, 프로트롬빈 유전자 돌연변이가 있는 경우 프로트롬빈 농도가 증가하게 된다. 현재 국내에서는 프로트롬빈 농도 를 직접 측정하는 검사는 시행하지 않고 있으며, 프로트롬 
빈 농도는 국제표준단위(INR)와 비교적 잘 일치한다는 연 구 결과가 있다. 내원 당시 증례 환자에서 국제표준단위 가 정상 소견을 보여 프로트롬빈 농도가 정상 범위에 있을 것으로 추정해 볼 수 있으며, 따라서 프로트롬빈 유전자 돌연변이가 혈전증의 원인일 가능성은 떨어질 것으로 생 각하였다.

JAK2 V617F 돌연변이가 있었으나 골수 증식성 질환을 시사하는 소견이 없었고 위험 인자 없이 심부혈전정맥증 과 함께 폐색전증이 발생하였다. 현재까지 심부혈전정맥 증과 함께 폐색전증이 발생한 환자에서 JAK2 V617F 돌연 변이가 발견된 증례는 보고된 바가 없었으며 폐색전증과 JAK2 V617F 돌연변이와의 연관성을 명확하게 밝혀낸 연 구 결과는 없다.

JAK2 V617F 돌연변이는 JAK2의 뉴클레오타이드 1849 에 존재하는 G 염기가 T 염기로 체성 변이됨으로써 617번 코돈의 Valine이 phenylalanine으로 치환되는 돌연변이를 말한다 ${ }^{8}$ JAK2 V617F 돌연변이가 발생하게 되면 세포 내 티로신 키네즈(cytoplasmic tyrosine kinase)의 활성도가 증가하게 되며 특히 혈액 생성과 관련된 세포에 영항을 주게 된다. 쥐 실험 결과 세포 내 티로신 키네즈의 활성화 는 원발성 혈소판 증가증, 진성 적혈구 증가증, 골수 섬유 화증 등과 같은 질환의 유도 및 과활성화를 유발시키는 것 으로 밝혀졌다. JAK2의 단일 점돌연변이(Val617Phe)는 필 라델피아 염색체 음성인 골수증식성 질환인 진성적혈구 증 가증 환자의 90 95\%, 원발성 혈소판 증가증 환자의 50 $60 \%$ 에서 관찰되는 것으로 보고되고 있다. 따라서 이는 골 수 증식성 질환의 진단에 많은 도움을 주고 있다 ${ }^{10}$.

중국의 한 병원에서 6개월 동안 무작위로 3,935명의 혈 액을 대상으로 시행한 JAK2 V617F 돌연변이 검사에서 $1 \%$ 인 37명에게서 JAK2 V617F 돌연변이가 확인되었다 ${ }^{11}$. 이 혈액을 다시 분석한 결과 오직 하나의 혈액에서만 진성 적혈구 증가증을 의심할 만한 결과가 나왔으며 나머지 36 명의 경우에는 적혈구나 혈소판 수치가 정상 범위에 있어 만성 골수 증식성 질환을 의심할 수 없었다. 이러한 결과 는 JAK2 V617F 돌연변이가 만성 골수 증식성 질환이 있 는 경우 높은 비율에서 발견되나 JAK2 V617F 돌연변이가 있는 모든 환자에서 만성 골수 증식성 질환의 발병률이 높다고 말할 수 없음을 의미한다.

1997년부터 2006년까지 네팔에서 시행한 연구에서, 99 명의 창자간막정맥 혈전증 환자 중 17명에서 JAK2 V617F 돌연변이가 발견되었다. 17명 중에서 이미 만성 골수 증 식성 질환을 진단받은 경우는 7명이었으며, 나머지 10명
을 41 개월 동안 추적관찰한 결과 3 명이 추적관찰 기간 동 안 만성 골수 증식성 질환을 진단받았다. JAK2 V617F 돌 연변이가 발견된 모든 경우에서, C 단백질 결핍, $\mathrm{S}$ 단백질 결핍, $\mathrm{V}$ 응고인자 레이덴 돌연변이와 같은 원발성 응고장 애는 발견되지 않았다 ${ }^{12}$. 반면 230 명의 대조군 중에서는 돌연변이가 발견된 사람은 한 명도 없었다. 비록 심부정 맥 혈전증이나 폐색전증에 대한 결과는 아니지만 다른 위 험 인자가 없고 흔하지 않은 위치에 정맥혈전증이 발생한 경우, 다른 원발성 응고장애가 발견되지 않았다면 JAK2 $\mathrm{V} 617 \mathrm{~F}$ 돌연변이가 원인일 가능성이 있다.

한편, 만성 골수 증식성 질환이 없고 정맥혈전증이 발 생한 139명의 환자를 대상으로 JAK2 V617F 돌연변이를 검사한 결과, 3명에서 JAK2 V617F 돌연변이가 발견되었 다. 하지만, 이들은 모두 창자간막정맥의 혈전증이 있는 환자였으며, 심부정맥혈전증 환자 61명 및 폐색전증 환자 53 명에서는 JAK2 V617F 돌연변이가 발견되지 않았다 ${ }^{13}$. 이러한 결과로 보아, 창자간막정맥 혈전증은 JAK2 V617F 돌연변이와의 연관성이 높다고 생각되나 심부정맥 혈전 증이나 폐색전증과 JAK2 V617F 돌연변이와의 연관성에 대해서는 좀 더 대규모의 연구가 필요한 것으로 생각된다.

본 증례 환자는 헤마토크리트가 $49.3 \%$, 혈소판 150,000 / $\mathrm{mm}^{3}$ 로 진성 적혈구 증가증이나 원발성 혈소판 증가증 등 의 골수 증식성 질환은 없었으나 JAK2 V617F 돌연변이 이외의 혈전증이 생길 만한 다른 위험 인자가 존재하지 않았다는 점에서 JAK2 V617F 돌연변이와 연관된 혈전증 의 발생을 배제할 수 없다. 따라서, 혈전증의 원인을 발견 할 수 없거나, 비정상적인 부위의 혈전 색전증에 있어서 JAK2 V617F 돌연변이가 존재할 가능성에 대해서도 고려 해 볼 수 있을 것으로 생각된다.

골수 증식성 질환이 없으나 JAK2 V617F 돌연변이 양성 이며 창자간막정맥 또는 뇌혈관의 혈전증이 발생한 환자를 추적관찰했을 경우 $30 \%$ 의 환자에서 결국 골수 증식성 질 환이 발생하였다는 연구 결과가 있다 ${ }^{14,15}$. 이는 $70 \%$ 의 환 자에서는 골수 증식성 질환이 발생하지 않았다는 것을 의 미하며 JAK2 V617F 돌연변이가 양성이라고 하여도 반드 시 골수 증식성 질환이 발생하지는 않는다는 것을 뜻한다.

본 증례 환자의 경우 18 개월 동안 외래 추적관찰을 통 해 이학적 검사 및 말초혈액검사를 시행하고 있으며 현재 까지는 폐색전증이나 심부혈전정맥증의 재발은 보이지 않고 만성 골수 증식성 질환을 의심할 만한 소견도 보이지 않고 있다. 하지만 JAK2 V617F 돌연변이가 있으므로 심 증적으로는 혈전증이 재발할 가능성이 다른 사람에 비해 
높을 것으로 생각되나 이에 대한 근거는 명확하지 않다. 따라서 혈전증의 재발 여부에 대해 꾸준한 외래 추적관찰 이 필요하며 골수 증식성 질환이 발생하지 않는지에 대한 추적 관찰이 역시 필요할 것으로 생각된다.

\section{참 고 문 헌}

1. Silverstein MD, Heit JA, Mohr DN, O'Fallon WM, Melton LJ 3rd. Trends in the incidence of deep vein thrombosis and pulmonary embolism: a 25-year population-based study. Arch Intern Med 1998;158:585-93.

2. Rosendaal FR. Venous thrombosis: the role of genes, environment, and behavior. Hematology 2005;1:1-12.

3. Wong RS, Cheng CK, Chan NP, Cheng SH, Wong WS, Lau KM, et al. JAK2 V617F mutation is associated with increased risk of thrombosis in Chinese patients with essential thrombocythaemia. Br J Haematol 2008;141: 902-4.

4. The British Committee for Standards in Haematology. Guidelines on the investigation and management of thrombophilia. J Clin Pathol 1990;43:703-9.

5. Tapson VF. Acute pulmonary embolism. N Engl J Med 2008;358:1037-52.

6. Gomez K, Laffan MA. Hunting for the mutation in inherited thrombophilia. Blood Coagul Fibrinolysis 2004; 15:125-7.

7. D'Angelo A, Della Valle P, Crippa L, Fattorini A, Pattarini E, Viganò D'Angelo S. Relationship between international normalized ratio values, vitamin K-dependent clotting factor levels and in vivo prothrombin activation during the early and steady phases of oral antico- agulant treatment. Haematologica 2002;87:1074-80.

8. James C, Ugo V, Le Couédic JP, Staerk J, Delhommeau $\mathrm{F}$, Lacout $\mathrm{C}$, et al. A unique clonal JAK2 mutation leading to constitutive signalling causes polycythaemia vera. Nature 2005; $334: 1144-8$.

9. Austin SK, Lambert JR. The JAK2 V617F mutation and thrombosis. Br J Haematol 2008;143:307-20.

10. Tefferi A. Classification, diagnosis and management of myeloproliferative disorders in the JAK2V617F era. Hematology Am Soc Hematol Educ Program 2006;1:240-5.

11. Xu X, Zhang Q, Luo J, Xing S, Li Q, Krantz SB, et al. JAK2 (V617F): prevalence in a large Chinese hospital population. Blood 2007;109:339-42.

12. Colaizzo D, Amitrano L, Tiscia GL, Scenna G, Grandone E, Guardascione MA, et al. The JAK2 V617F mutation frequently occurs in patients with portal and mesenteric venous thrombosis. J Thromb Haemost 2007;5:55-61.

13. Rossi D, Cresta S, Destro T, Vendramin C, Bocchetta S, De Paoli L, et al. JAK2V617F in idiopathic venous thromboembolism occurring in the absence of inherited or acquired thrombophilia. Br J Haematol 2007;138: 813-4.

14. Regina S, Herault O, D'Alteroche L, Binet C, Gruel Y. JAK2 V617F is specifically associated with idiopathic splanchnic vein thrombosis. J Thromb Haemost 2007; 5:859-61.

15. De Stefano V, Fiorini A, Rossi E, Za T, Farina G, Chiusolo $\mathrm{P}$, et al. Incidence of the JAK2 V617F mutation among patients with splanchnic or cerebral venous thrombosis and without overt chronic myeloproliferative disorders. J Thromb Haemost 2007;5:708-14. 